\title{
A controlled trial of a protein-free liver extract in the treatment of chronic liver disease
}

\author{
P. J. TOGHILL, R. P. KNILL-JONES, AND ROGER WILliaMS \\ From the Liver Unit, King's College Hospital, London
}

SUMmARY A double-blind trial of a protein-free liver extract (Ripason) which was administered both orally and intramuscularly is described in 20 patients with stable cirrhosis. Control and treated groups were similar in composition except for age. Both groups showed some symptomatic improvement during the trial. Fewer patients were recorded as worse on Ripason but no significant changes in body weight, haemoglobin, or liver function tests could be detected.

Purified liver extracts have been used for a number of years in the treatment of both acute and chronic liver disease. Ripason, a protein-free liver extract, was introduced in 1953 and has been shown to have beneficial effects in both experimental and clinical studies. Burri (1953) and Hartmann (1953) showed it to have a lipotropic effect in the carbon tetrachloride damaged rat liver and Roulet (1958), also using rats, demonstrated a protective effect of this extract in the induction of cirrhosis by choline deficiency. In rabbits it may stimulate regeneration of liver parenchyma after partial hepatectomy (Grifoni and Rucci, 1962).

A large number of clinical reports on the use of oral and parenteral preparations of Ripason have indicated its value in various types of acute and chronic hepatic disease (Paraf, 1954; Stiefel and Jasinski, 1963; Gutewa, 1962; Dioguardi, 1956). However, all these trials have been uncontrolled and often involved only subjective assessment of the patients' improvement. In this paper we present the results of a double-blind controlled trial of Ripason therapy in chronic liver disease.

\section{DESIGN OF TRIAL}

Twenty-four adult patients with histologically proven cirrhosis were admitted to the trial, and were randomly allocated into two groups. At the onset of the trial their liver disease was well compensated and clinically stable. Two died during the early part of the trial, both from hepatomas, one reverted to taking large quantities of alcohol and one was withdrawn because of a sensitivity reaction after the second injection of Ripason.

Twenty patients completed the trial and consisted of two groups receiving either Ripason or placebo on a double-blind basis. Six patients out of the 10 in the
Ripason group and seven of the placebo group were males. The two groups contained similar numbers of patients with different varieties of cirrhosis (Table I) and similar numbers of patients with abnormal tests at the onset of the trial (Fig. 1). The differences in the means of each measurement between the groups at the beginning of the trial were also not significant. However, the patients in the placebo group were on average 13.2 years older than the patients receiving Ripason (Table II), this difference being significant $(P<0.01)$. We concluded that since the two groups were otherwise well matched the different age distributions represented a chance occurrence due to small numbers and that this would not affect the results of the trial. Similar discrepancies have occurred in trials concerning larger numbers of

TABLE I

NUMBERS OF PATIENTS AND DIAGNOSIS IN EACH GROUP

\begin{tabular}{lll} 
Diagnosis & Ripason & Placebo \\
\hline Alcoholic cirrhosis & 4 & 5 \\
Cryptogenic cirrhosis & 5 & 4 \\
Active chronic hepatitis & 1 & 1
\end{tabular}

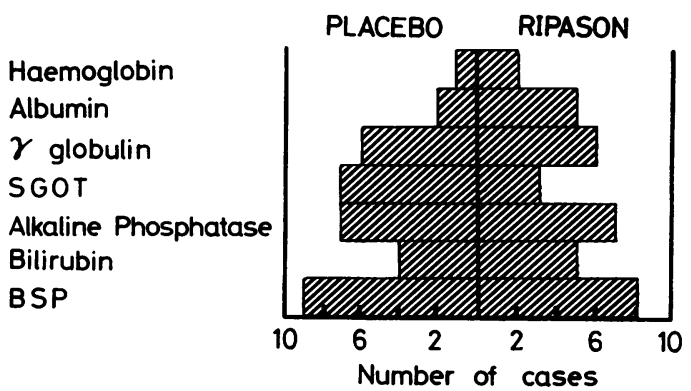

FIG. 1. Numbers in each group having abnormal results in those tests used in the assessment. 
TABLE II

AGE DISTRIBUTION OF THE TWO GROUPS

\begin{tabular}{llllllll}
\multicolumn{2}{l}{ Age $(\mathrm{yr})$} & & & \\
\cline { 2 - 7 } & $20-$ & $30-$ & $40-$ & $50-$ & $60-$ & $70-$ & Mean $\pm S E$ \\
\hline Ripason 1 & 1 & 3 & 4 & 1 & - & $47 \cdot 6 \pm 3 \cdot 6$ \\
Placebo - & - & 2 & 2 & 3 & 3 & $60.8 \pm 3.6$
\end{tabular}

patients and were ascribed to chance fluctuations (Report by the Medical Research Council working party on the treatment of myocardial infarction, 1968).

Each patient was observed on monthly occasions for seven months, twice before treatment was started, three times during treatment, and twice after treatment. At every attendance each patient was asked a series of standard questions regarding general well-being and appetite and was also examined for liver and spleen size, the presence of ascites or ankle oedema, and for signs of porto-systemic encephalopathy. The following measurements were made: weight; haemoglobin; total white cell count; erythrocyte sedimentation rate; total serum bilirubin with conjugated and unconjugated fractions, total plasma proteins with albumin, $\alpha_{1}$ globulin, $\alpha_{2}$ globulin, $\beta$ globulin, and $\gamma$ globulin fractions; serum aspartate aminotransferase; alkaline phosphatase; blood urea; serum electrolytes. Bromsulphalein excretion was measured using the method of Seligson, Marino, and Dodson (1957) with samples taken at 5, 10, 20, and 30 minutes, the results being expressed as the halfclearance time in minutes.

Ripason and placebo were administered both parenterally and orally. Each patient received $2 \mathrm{ml}$ of solution by intramuscular injections three times a week for three months and also received two tablets three times a day, three times a week for three months, the tablets being taken on days when the injections were not administered. The placebo injections and tablets contained a 1 in 10,000 solution of Ripason.

At the end of the trial but before the code was broken the patients and the physicians gave a numerical assessment of their overall progress as follows: much better +2 ; better +1 ; the same 0 ; worse -1 ; much worse -2 .

\section{RESULTS}

In the overall assessment of progress of the Ripason group during the trial the patients' assessment scores gave a total of +9 whereas the physician's assessment (of the corresponding group) was +4 . For the placebo group the values were +4 and +2 respectively. Changes in well being and appetite are shown in Table III separately.

The haemoglobin concentration and some of the more important liver function tests were analysed. Those taken were: albumin; serum globulin; serum aspartate aminotransferase (SGOT); alkaline phos-

\section{TABLE III}

SYMPTOMATIC CHANGES IN THE TWO GROUPS

\begin{tabular}{llll} 
Group & \multicolumn{3}{l}{ Change } \\
\cline { 2 - 3 } & Better & Same & Worse \\
\hline
\end{tabular}

Ripason well-being appetite

$\begin{array}{lll}2 & 8 & 0 \\ 3 & 6 & 1\end{array}$

Placebo well-being appetite

$\begin{array}{lll}4 & 4 & 2 \\ 5 & 3 & 2\end{array}$

phatase; bilirubin and bromsulphalein excretion. As there is no simple, single test for objective assessment of liver function, degrees of change in each test had to be considered.

The results of progress in the trial have been expressed as mean changes of the three observations in the treatment phase and the two observations in the post-treatment phase compared respectively for each patient, with the mean basal values. It can be seen from Table IV that there has been no significant change in any of the specific measurements.

The bromsulphalein excretion results have been recorded graphically (Fig. 2). In one patient in the group on Ripason (indicated by the heavy line) there was a significant improvement over the period of observation and in this case the rather wide variation of the two basal recordings makes the later observations difficult to interpret.

\section{DISCUSSION}

In animal experiments this protein-free liver extract

TABLE IV

MEAN CHANGES FROM THE PRETREATMENT PERIOD WHICH OCCURRED DURING AND AFTER TREATMENT IN THE RIPASON AND CONTROL GROUPS ${ }^{1}$

\begin{tabular}{|c|c|c|c|c|}
\hline \multirow[t]{2}{*}{ Estimation } & \multicolumn{2}{|l|}{ Ripason } & \multicolumn{2}{|l|}{ Placebo } \\
\hline & During Treatment & After Treatment & During Treatment & After Treatment \\
\hline $\begin{array}{l}\text { Body weight }(\mathrm{kg}) \\
\text { Haemoglobin }(\mathrm{g} / 100 \mathrm{ml}) \\
\text { Albumin }(\mathrm{g} / 100 \mathrm{ml}) \\
\gamma \text { Globulin }(\mathrm{g} / 100 \mathrm{ml}) \\
\text { SGOT }(\mathrm{IU} / 100 \mathrm{ml}) \\
\text { Alkaline phosphatase }(\mathrm{K}-\mathrm{A} \mathrm{U} / 100 \mathrm{ml}) \\
\text { Bilirubin }(\mathrm{mg} / 100 \mathrm{ml})\end{array}$ & $\begin{array}{l}+1.74 \pm 1.06 \\
+0.54 \pm 0.38 \\
0.0 \pm 0.31 \\
-0.09 \pm 0.17 \\
+5.2 \pm 11.4 \\
-0.41 \pm 3.0 \\
+0.03 \pm 0.12\end{array}$ & $\begin{array}{l}+2.14 \pm 1.54 \\
+0.79 \pm 0.45 \\
+0.04 \pm 0.30 \\
+0.31 \pm 0.13 \\
+3.1 \pm 5.6 \\
+5.2 \pm 4.6 \\
+0.62 \pm 0.33\end{array}$ & $\begin{array}{l}+1.92 \pm 0.71 \\
+0.02 \pm 0.64 \\
+0.23 \pm 0.19 \\
+0.03 \pm 0.24 \\
-13.1 \pm 14.6 \\
+1.95 \pm 1.4 \\
-0.15 \pm 0.08\end{array}$ & $\begin{array}{l}+2.46 \pm 0.88 \\
+0.35 \pm 0.71 \\
+0.35 \pm 0.23 \\
+0.21 \pm 0.18 \\
+10.9 \pm 23.3 \\
+1.4 \pm 14 \\
-0.06 \pm 0.19\end{array}$ \\
\hline
\end{tabular}

1 standard error. 


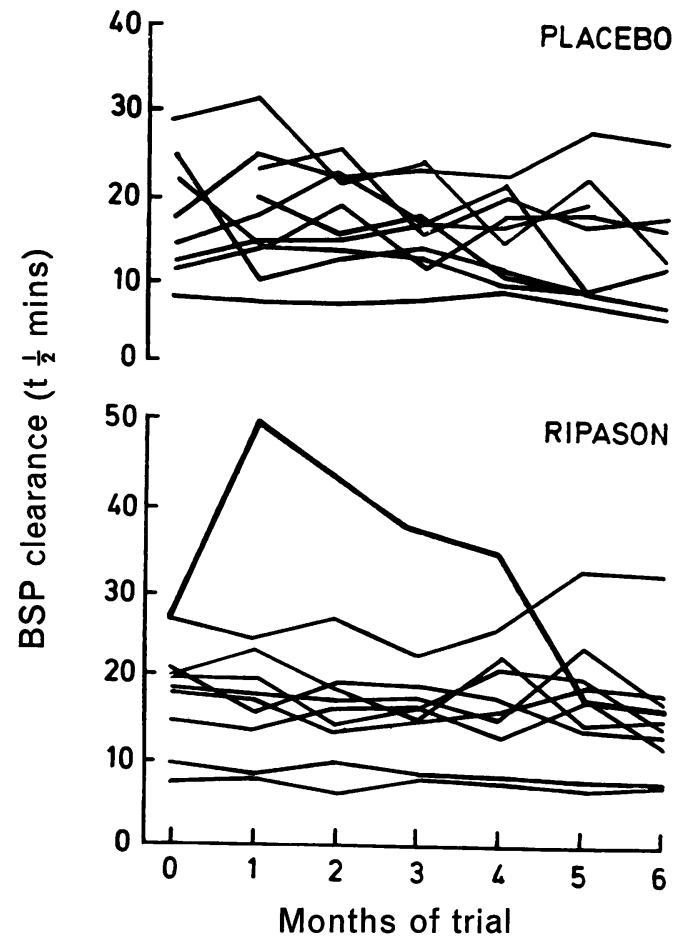

FIG. 2. Results of bromsulphalein (BSP) clearances in individual patients of placebo and treated group.

exerts a specific effect on hepatic tissue. In 1956, Grupp and Roulet showed in guinea-pigs that the extract caused increased oxygen consumption in a liver tissue slice preparation. Reference has already been made to the work of Roulet (1958) on its protective effect against cirrhosis induced by choline deficiency and that of Burri (1953), Hartmann (1953), and Tanyol and Friedman (1961) showing a decrease in the degree of fatty infiltration produced by carbon tetrachloride poisoning. In man the beneficial action of Ripason has been reported in many hepatic disorders, such as prolonged infective hepatitis, compensated cirrhosis, and fatty degeneration of the liver (Kallai and Cerlek, 1955). Most of these reports have described subjective improvement noticed by the patient or have been based on clinical examination of the patient (Dentan, 1956). However, Gutewa (1962) in a careful study recorded the results of serial clinicopathological tests and concluded that Ripason significantly improved transaminase levels and bromsulphalein excretion.

The difficulty of assessing changes in patients with chronic hepatic disease is well known since the course of cirrhosis is variable. Some patients with cirrhosis pursue a steadily deteriorating course while in others more rapid phases of deterioration occur following bleeding from oesophageal varices or the development of ascites. In this trial patients were selected who had well-compensated cirrhosis and whose condition had been relatively stable for the preceding six months without recent episodes of bleeding. On the other hand, regular medical supervision with abstinence from alcohol in some patients might be expected to confer a certain degree of benefit.

The good symptomatic effect of Ripason has been stressed in earlier publications (Falkner, Hammerschmidt, and Neumayr, 1954). In our patients an increased sense of well being and an improved appetite were noted in both groups, with a slightly better result in the placebo group. Fewer patients were 'worse' on Ripason than on placebo (Table III). Using an arbitrary scoring system for assessment, patients reported greater subjective benefit from Ripason than from placebo treatment. An overall increase in weight occurred in both groups although this was only significant for the placebo group, both during and after treatment. Retention of fluid was not detected clinically in any of the patients. No evidence for a diuretic effect of Ripason as described by Stiefel and Jasinski (1963) was found.

It is very difficult to make objective observations in a trial of this kind. It is well known that histological evidence of chronic liver disease may not necessarily be accompanied by changes in the routine laboratory tests of liver function. Under these circumstances it will be impossible for 'improvement' to be demonstrated following any treatment. The design of the trial allowed comparison of the change in values from the pretreatment period to the treatment periods, thus reducing between patient variation. However, no significant changes were detected and no consistent trends appeared during the study. Bromsulphalein excretion, which is a sensitive test of liver function, remained constant throughout the trial except in the one patient mentioned earlier who was on Ripason.

Only one possible reaction was encountered in more than 500 injections of full strength and diluted Ripason. This man developed rigors two to three hours after his second injection and had to be withdrawn from the trial. Two other patients complained of skin itching but this was never severe. This preparation therefore appears to be relatively free from side effects whether given intramuscularly or orally. Finally, although this was a double-blind trial the 'placebo' did contain a very small dose of Ripason $(1$ in 10,000). The possibility that the symptomatic improvement noted in both the groups was due to trace compounds contained in the preparation cannot be excluded. 
We are grateful to Dr Ralph Kohn and Dr W. Rosenberg of Robapharm Ltd for their very considerable help with this trial and to Mr M. P. Curwen for statistical assistance.

\section{REFERENCES}

Burri, M. (1953). Zur tierexperiment ellen Prüjung eines neven Lebertotalextraktes. Experientia (Basel), 9, 385-387.

Dentan, A. (1956). à l'étude du traitment des hepatopathies chronique par un extrait total ac joie. Praxis, 45, 1105-1108.

Dioguardi, N. (1956). Considerazioni intorno al trattamento di alcuni stati epatopatici con estratti acquosi crudi e dealbuminizzat i. Progr. med. (Napoli), 12, 627-633.

Falkner, R., Hammerschmidt, M., and Neumayr, A. (1954). Ueber die Behandhing von Leberparenchymer-krankungen mit einem lebercoeal extract. Wien. klin. Wschr., 66, 779-785.

Grifoni, F., and Rucci, F. S. (1962). L'azione degli estratti totali di jegato sui poteri rigenerative del parenchima epatico: aspetti ponderali and morjologici dopo resezione sperimentale. Gazz. med. ital., 121, 87-99.

Grupp, G., and Roulet, F. C. (1956). Über den Einfluss von Organextrakten auf den Sauerstojlverbrauch von Geweben. Experientia (Basel), 12, 433-434.
Gutewa, J. (1962). Behandlungsergebnis mit einem eiweissfreien Leberextrakt. Praxis, 51, 444-449.

Hartmann, F. (1953). Versuche über die Lipotrope wirkung eines Leberextraktes. Klin. Wschr., 31, 720.

Kallai, L., and Cerlek, S. (1955). Traitement des hépatopathies par un extrait de joie total. Acta Gastro-ent. belg., 18, 303-619.

Medical Research Council. (1968) Potassium, glucose and insulin treatment for acute myocardial infarction (Report by working party on Treatment of Myocardial Infarction) Lancet, 2, 13551306.

Parai, A. (1954). Nouvelel extrait total du joie injectable par voie veineuse dans la traitement de la cirrhose du joie. Rev. int. Hépat., 4, 399-403.

Roulet, F. C. (1958). Versuche über die experimentalle Lebercirrhose durch Cholinmangel und deren therapeutische Beeinflussung. Schweiz. med. Wschr., 88, 86-89.

Seligson, D., Marino, J., and Dodson, E. (1957). Determination of sulfobromophthalein in serum. Clin. Chem., 3, 638-645.

Stiefel, G. E., and Jasinski, B. (1963). Liver extract 'Ripason', indications and effects. Survey of ten years' experimental and clinical results. Praxis, 52, 367-371.

Tanyol, H., and Friedman, M. H. F. (1961). Influence of a liver preparation on liver of cats receiving carbon tetrachloride. Proc. Soc. exp. Biol. (N. Y.), 106, 645-648. 